\title{
Money and Capital \\ The Contributions of Capital \\ in the Twenty-First Century \\ to Monetary History and Theory
}

Éric Monnet

Is money a particular form of capital? If so, and if nonmonetary capital can potentially be changed into money, then what are the consequences for the history and theory of capital? These questions are not explicitly at the center of Thomas Piketty's argument in Capital in the Twenty-First Century, but they do surface on several occasions and are essential for many distinctions made in the book. Indeed, the history of capital cannot be written without monetary history.

\section{Money Counted as Capital}

In accounting terms, and according to current conventions in national accounting, money belongs to capital in the sense that the latter is defined as the total of everything making up an individual's wealth. There is no distinction-contrary to the one made by Karl Marx, for example-between money used as a means of exchange and money used for the accumulation of capital. ${ }^{1}$ Basing his analyses

This article was translated from the French by Darla Gervais and edited by Chloe Morgan, Nicolas Barreyre, and Stephen Sawyer.

1. According to Marx, there are two kinds of exchange or circulation of merchandise. The first is the transformation of merchandise into money: "selling to buy." The second is the transformation of money into merchandise followed by its retransformation into money: "buying to sell." It is only when money (as a currency) follows this latter form of circulation that it "becomes capital, and is already potentially capital." See Karl Marx, Capital: A Critique of Political Economy, trans. Ben Fowkes (New York: Penguin Classics, 1992), bk. 1, "The Process of Production of Capital," 1:102. 
and his empirical work on this approach, Piketty includes a relatively short yet very interesting history of national accounting in his book. Assessing capital had become more or less a forgotten goal at the time when quarterly and annual national accounting as we know it today was being created, and it was not until the 1990s that the total national stock of wealth again became a priority for statistical institutions. Nevertheless, fiscal statistics make it possible to reconstruct much longer datasets, starting as early as the eighteenth century for France and the United Kingdom. The heyday of capital accounting lasted from the end of the nineteenth century to the First World War, a period when the level of capital compared to incomes reached an all-time high. In 1889, the great Scottish economist Robert Giffen published a work entitled The Growth of Capital that presented a specific method and precise estimates, building on previous studies, notably those of William Petty. In these nineteenth-century statistical studies, the question of the possible distinction between money and capital was resolved simply, since the stock of metallic currency was integrated into the stock of national capital. Since the United Kingdom was experiencing a heated monetary debate at the time-most notably over whether credit counted as money and whether the issuing of money increased national capital ${ }^{2}$ - the absence of any reference to these theoretical disputes in Giffen's work may seem somewhat surprising. The author did not discuss the possible difference between money and capital, but he placed the question of the monetary value of capital at the center of his work, thus recognizing that capital had value because it could be resold (at its market value) and thereby become money once again. ${ }^{3}$

In many respects Piketty follows in the footsteps of Giffen, whom he cites on several occasions. He adopts an accounting approach to capital throughout the majority of the book, except when he presents his theory of the dynamics of capital, which depends on the difference between the real rate of return on capital and the growth rate of per-capita income (where money does not play any role at all). As to the question of nominal value, it is mostly dealt with by dividing the stock of capital by total incomes rather than investigating the links between real and nominal capital. In other words, Piketty's choice of the accounting approach, as he specifies clearly at the beginning of his book, implies that he considers "capital" and "wealth" to be perfectly synonymous. ${ }^{4}$ This choice essentially means that money stock is included within capital, thus glossing over a possible theoretical distinction between money and capital.

2. See in particular the heated debate between the "currency school" and the "banking school," as well as all the controversies that followed the temporary suspension of the pound sterling's convertibility and lasted until the Peel Act of 1844 separated monetary issuance and banking activity within the Bank of England.

3. Robert Giffen, The Growth of Capital (London: G. Bell, 1889), 61.

4. Thomas Piketty, Capital in the Twenty-First Century, trans. Arthur Goldhammer (Cambridge/London: Harvard University Press, 2014), 47. 


\section{Theoretical Differences Between Money and Capital}

This is not the place to recount the complete history of the various theories of money and capital, but it seems important to underline the fact that economists still do not agree on whether money is or is not capital, let alone on how the latter depends on the former. Most see money as simply a means of completing transactions for purchasing goods, in no way linked to capital accumulation or the production of real riches. In the vast majority of neoclassical and Keynesian models, capital is distinguished from money because it enters into the process of production without necessarily using money. ${ }^{5}$ It may not seem particularly surprising that in the real world the amount of monetary assets held is considered to be positively correlated with the size of one's (nonmonetary) personal wealth, an observation that fits perfectly well with Piketty's general account of the distribution of capital. Such a correlation, however, contradicts a large number of economic theories in which money is considered to be a neutral element, which, since it is a tool used in transactions, should only be correlated to consumption. ${ }^{6}$

This theoretical distinction, which is the basis of the difference between money and capital, asserts that the latter generates a real return, while the former generates only a liquidity feature, barely if at all remunerated. ${ }^{7}$ In contrast to Marx's theory that money made the accumulation of capital possible, other theories rely on the assumption that holding money generates an opportunity cost, since monetized wealth does not generate interest. Milton Friedman, for instance, asserted that holding money is cost-free only if the nominal interest rate is equal to zero. ${ }^{8}$ In

5. In these models, agents maximize a production function (including capital and labor) subject to a budgetary constraint. Money will appear, either in the utility function of each agent or within the budgetary constraint, as a limit on transactions; alternatively, it can be a way to "smooth" the budgetary constraint over several cycles through savings or through the transfer of liquid assets from one period to another. There have been attempts at introducing money into the production function, but they have never generated convincing theoretical conclusions: see Stanley Fischer, "Money and the Production Function," Economic Inquiry 12, no. 4 (1974): 517-33. Institutionalist theories of money, such as those of Marcel Mauss, Michel Aglietta, André Orléan, or Karl Polanyi, provide a different series of perspectives to which we will return, but none of them grant particular importance to the distinction between money and capital.

6. Xavier Ragot, "The Case for a Financial Approach to Money Demand," Journal of Monetary Economics 62 (2014): 94-107.

7. For an attempt to theorize capital as money, that is, as an element of the production function that also provides a liquidity feature, see Ricardo Lagos and Guillaume Rocheteau, "Money and Capital as Competing Media of Exchange," Journal of Economic Theory 142, no. 1 (2008): 247-58.

8. There is an opportunity cost to the holding of money rather than assets generating a positive return. For this opportunity cost to be equal to zero, the nominal interest rate must also be equal to zero, which means that the central bank would have to achieve a negative inflation rate equal to the opposite of the real rate of interest on safe assets. See Milton Friedman, The Optimum Quantity of Money, and Other Essays (London: Macmillan, 1969). 
these models, money is a substitute for a certain type of capital—namely financial capital, principally government bonds-, but is not a precondition for it. According to such theories, in other words, as soon as money functions as a store of value in addition to its role as a tool for payments it stops being money, strictly speaking, and becomes capital, since it is fixed and generates a positive real return. John Maynard Keynes also defended a similar distinction, but, far from adopting the neutral money of neoclassical theory, he explored the way money and capital could be substitutes, devoting two whole chapters to this issue. He was thus interested in the relative rates of return on both types of assets. ${ }^{9}$ He explained that capital could be accumulated or generated only if the rates of return on it were larger than the rates of return on money, and that there was no reason to assume that market mechanisms would lead to perfectly equal interest rates on money and on capital.

\section{Money as a Particular Type of Capital and the Consequences of Inflation}

Piketty's highly successful approach to money and capital accounting, including the former in the latter and sidestepping the endless debates on the nature of money, would seem to make the epistemological debates over the nature of money or the distinction between money and capital outdated and sterile. Still, the issue of money resurfaces several times in the book, proving that its dismissal is not as straightforward as it seems.

First, Piketty mentions inflation as potentially equivalent to the taxation of capital. ${ }^{10}$ Inflation, as long as it is an across-the-board inflation of price levels, will decrease real wealth: the real value of capital decreases because its nominal value is fixed while prices increase. This is necessarily true for money (and thus for part of capital), but also for nonmonetary financial securities. The nominal value of a Treasury bond worth 10,000 euros will be the same ten years from now, but its real value will have been diminished by the amount of inflation that takes place. There is therefore a type of capital whose value decreases with inflation, which in this case is a tax on money. If, however, inflation only concerns the price of some assets and not the general price level-that is, if it does not act as a tax on moneyit can actually increase the value of capital; this is the case, for instance, with real estate or land. Thus, inflation decreases the real value of capital if it acts as a tax on money, but increases it if it is limited to an increase in the price of real estate. As Piketty explains, it then becomes necessary to make a distinction between nominal assets (money, time deposits, non inflation-indexed public or private bonds), for which the risk of inflation is high, and real assets (real estate, stocks, etc.). To find out the real rate of return on a nominal asset, inflation must be deducted from 
interest payments, while for a real asset, such an operation is unnecessary. ${ }^{11}$ Piketty observes that on average over three-quarters of household assets are made up of real assets, and consequently considers that the average return on capital can be approximated without deducting inflation. ${ }^{12}$

The situation is more complex, however, since money and (non-monetary) capital are partly substitutable. If inflation of the general price level increases, then economic agents can get rid of their money and other nominal assets (mostly Treasury bonds not indexed on inflation) and reinvest in real estate, for example. This will increase the price of real estate in proportion, and will thus bring about an increase in the value of capital, which can in turn feed inflation, for instance through upward pressure on wages. All these details are crucial to understanding why the inflationist tax is not a global tax on all capital, and cannot in and of itself bring about "the euthanasia of the rentier." 13 Again, Piketty is very explicit, even if all these details are rather peripheral to the central argument of the book. He concludes in a footnote that "an increase of inflation from 0 to 2 percent in a society where the return on capital is initially 4 percent is certainly not equivalent to a 50 percent tax on income from capital, for the simple reason that the price of real estate and stocks will begin to increase at 2 percent a year, so that only a small proportion of the assets owned by households-broadly speaking, cash deposits and some nominal assets-will pay the inflation tax." 14

Because of the complex phenomena of substitution between money and capital, Piketty comes to the conclusion that, compared to a direct tax on capital, inflation does not work as an instrument of wealth redistribution because it is "a relatively crude and imprecise tool." 15 Indeed, inflation can influence the distribution of capital in multiple and contradictory ways, depending on whether it corresponds to a change in the general price level, in the wage level, or in the price of certain assets. Inflation in consumer goods prices, fueled by wage increases and with no corresponding increase in housing rentals or real estate prices, will favor the poorest workers, while price increases driven by housing rentals and real estate with no change in wages will favor property owners. Thus, the choice between a tax on money (inflation) and a tax on capital depends on the possibility of substituting money and capital.

11. Ibid., 210-11, also 452ff. As a reminder, the return on capital is calculated by dividing all incomes from capital (in nominal terms) by the (also nominal) value of the total capital stock. Moreover, real assets are said to generate a return, or capital gains, while for nominal assets we talk of interest rates.

12. Ibid., 211-12.

13. The idea that inflation is the euthanasia of the rentier is often attributed to Keynes, but this is an error: there is no trace of such a statement in Keynes' work. On the contrary, Keynes asserts, in terms very similar to Piketty's, that the euthanasia of the rentier is brought about by a decrease in the marginal rate of return on capital. See Keynes, General Theory, bk. 4, chap. 16.

14. Piketty, Capital, 599 n. 13.

15. Ibid., 547. 
The second passage in which Piketty discusses the relationship between money and capital is found in his chapter focusing on public debt. In it, he argues that an increase in the monetary issue of a central bank does not increase the national stock of capital either immediately or automatically. ${ }^{16}$ When a central bank prints money, it does not distribute bags of banknotes to the population for free. Rather, it creates money through credit mechanisms, with banks borrowing amounts of money that are pure monetary creation. Because these banks (or the government) then become debtors, there is no immediate increase in the stock of capital from an accounting point of view, even though the share of money in the overall stock of capital does increase. However, the book concedes that monetary policy may indeed influence capital through indirect ulterior effects, for instance by preventing the failure of businesses or because of its impact on inflation and asset prices.

Overall, Piketty accounts for capital in a way that is strongly reminiscent of personal wealth balance sheets, probate inventories, or the national wealth censuses of the nineteenth century, in the tradition of Giffen. The goal is to list everything that is owned by an individual or a nation, minus debts (i.e., in terms of net wealth), at a given point in time, and to assess the total amount of these properties using their market value. Means of payment are necessarily included in these lists-with the result that the link with the various economic theories of capital becomes less than obvious. The exercise seems relatively compatible with Marx's conception of capital as accumulated money, though Marx himself also envisaged a possible noncapitalistic role for money. Therefore, any good which can be turned (back) into money is capital, potentially generating surplus value. ${ }^{17}$ But there is less agreement with neoclassical theory, which sharply distinguishes between capital and money, considering capital to be an element that generates real returns, its nominal value being relatively unimportant. The issue, which is linked to the "Cambridge controversy" and has already been raised by numerous critics of Piketty's book, is whether it is meaningful to speak of a rate of return on capital when it is made up of a wide variety of assets, including money. While the book eventually comes back to neoclassical theory, calculating the rate of return on capital by taking into account all the elements included in personal estates and comparing this rate to the rate of growth, Piketty's definition of capital still seems much more expansive than the one prescribed by this theory. This is because he uses the term synonymously with personal wealth, and therefore includes any riches associated with the latter (including, implicitly, social power).

16. Ibid. For a more detailed explanation of how central banks' assets are taken into account in the calculation of public capital, see the annexes in Thomas Piketty and Gabriel Zucman, "Capital is Back: Wealth-Income Ratios in Rich Countries 17002010," Quarterly Journal of Economics 129, no. 3 (2014): 1255-310. I thank Guillaume Bazot for his enlightening remarks on the topic.

17. On the taking into account of capital gains, see Piketty, Capital, 211. 


\section{Capital and Monetary History: Three Possible Extensions of the Argument}

Piketty's book thus opens numerous fruitful avenues for further inquiries into monetary and financial history - that is, the study of how the various types of capital (including money) are substitutable and the different ways of accumulating them. Because it provides a general treatment of capital within a long-term perspective, the book does not offer full answers to these questions, but does point toward new fields of research. It does not furnish explanations for all types of substitutions occurring within personal wealth over hundreds of years, but it does highlight potential paths forward and develop some of these issues at length, as with its discussion of slavery or its explanation of the demise of landed capital. ${ }^{18}$ In the same spirit, over the following pages I will sketch out a few possible extensions of the history of capital seen through the prism of monetary history.

\section{The Monetary Part of Capital}

A first possible way to extend the study would be to focus on the monetary part of capital as it appears in Piketty's narrative and in personal wealth balance sheets. As the book clearly demonstrates, this share is on average relatively small in quantitative terms but it may be very important in economic terms if, for instance, money is what makes the accumulation of capital possible (as Marx argued), or if money functions as an asset substitutable for capital, as is the case in several standard models of financial arbitrage. It then becomes possible to ask how much money is necessary to allow for capital accumulation, and to wonder whether the ratio between these two components is stable over time. Piketty's plentiful database does not provide a detailed breakdown of the monetary component within nineteenth and twentiethcentury capital. But it is possible to use other sources offering datasets relating to money supplies. These series must be used very cautiously, since there are numerous vagaries in the way they were constructed, and they are not based on the same sources as the series on capital (including money) published in Capital in the TwentyFirst Century. ${ }^{19}$ I will use the datasets built by Moritz Schularick and Alan Taylor, who chose an expansive definition of the money supply (M2) including coins, banknotes, and deposit accounts, and I will focus on two cases: France and the United Kingdom. ${ }^{20}$ A first striking result, confirmed by datasets from other countries, is that the long-term evolution of the money supply is very different from that of

18. Piketty, Capital, 158ff. and 196ff.

19. However, the datasets on monetary assets in the national wealth balance sheets since 1970, used in Piketty and Zucman, "Capital is Back," in terms of percentage of capital, are similar to the money supply datasets that I will use here.

20. Moritz Schularick and Alan M. Taylor, "Credit Booms Gone Bust: Monetary Policy, Leverage Cycles, and Financial Crises, 1870-2008,” American Economic Review 102, no. 2 (2012): 1029-61. 


\section{Figure 1 - Evolution of the capital (private personal wealth)/ money ratio (1880-2000)}

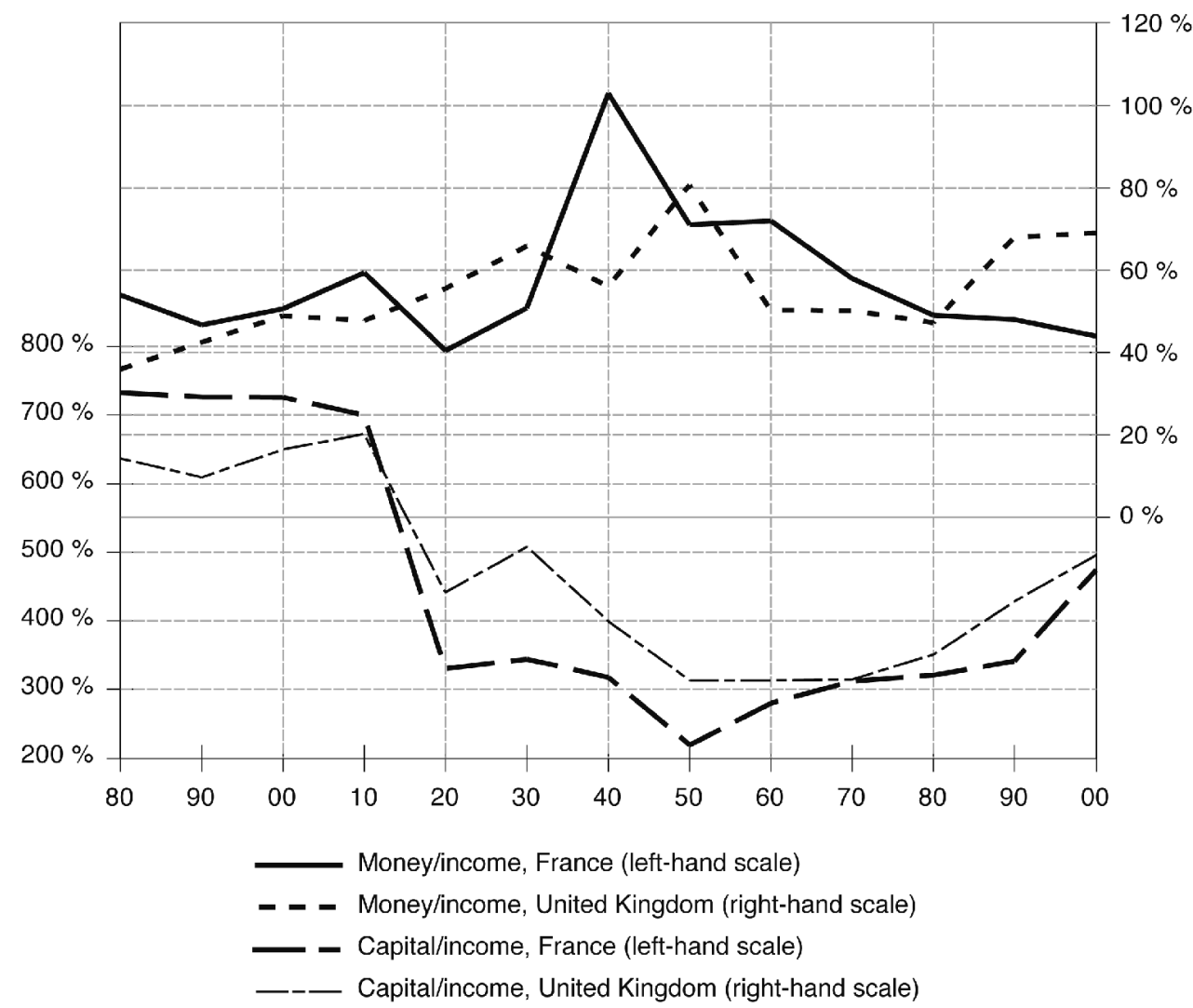

Sources: Schularick and Taylor, "Credit Booms Gone Bust"; Piketty, Capital.

capital (figure 1). Compared to capital divided by national income, the ratio of money supply divided by national income is relatively stable, in accordance with the quantity theory of money. Most importantly, it does not display any U-shaped curve in the twentieth century. On the contrary, one sees a slow increase, peaking in the mid-century, which suggests that its evolution was the opposite of that of capital. The money/capital ratio for France and the United Kingdom would thus follow a bell-shaped curve over the century (figure 2). There are several possible explanations. First, this may be the consequence of an arbitrage between assets based on their relative prices. The periods during which the ratio money/capital was highest, i.e., the 1950s and 1960s, were also periods characterized by low real rates of return for nonmonetary financial assets such as government bonds, and by growth rates that were often faster than rates of return on capital. In this case, the instrumental utility of monetary balances held is increased: a larger share of capital in the national income requires less cash to be held in reserve if capital is 40 less mobile than labor. More generally, although Piketty's book contains initial 
Figure 2 - Evolution of the money supply/private capital ratio (1880-2000)

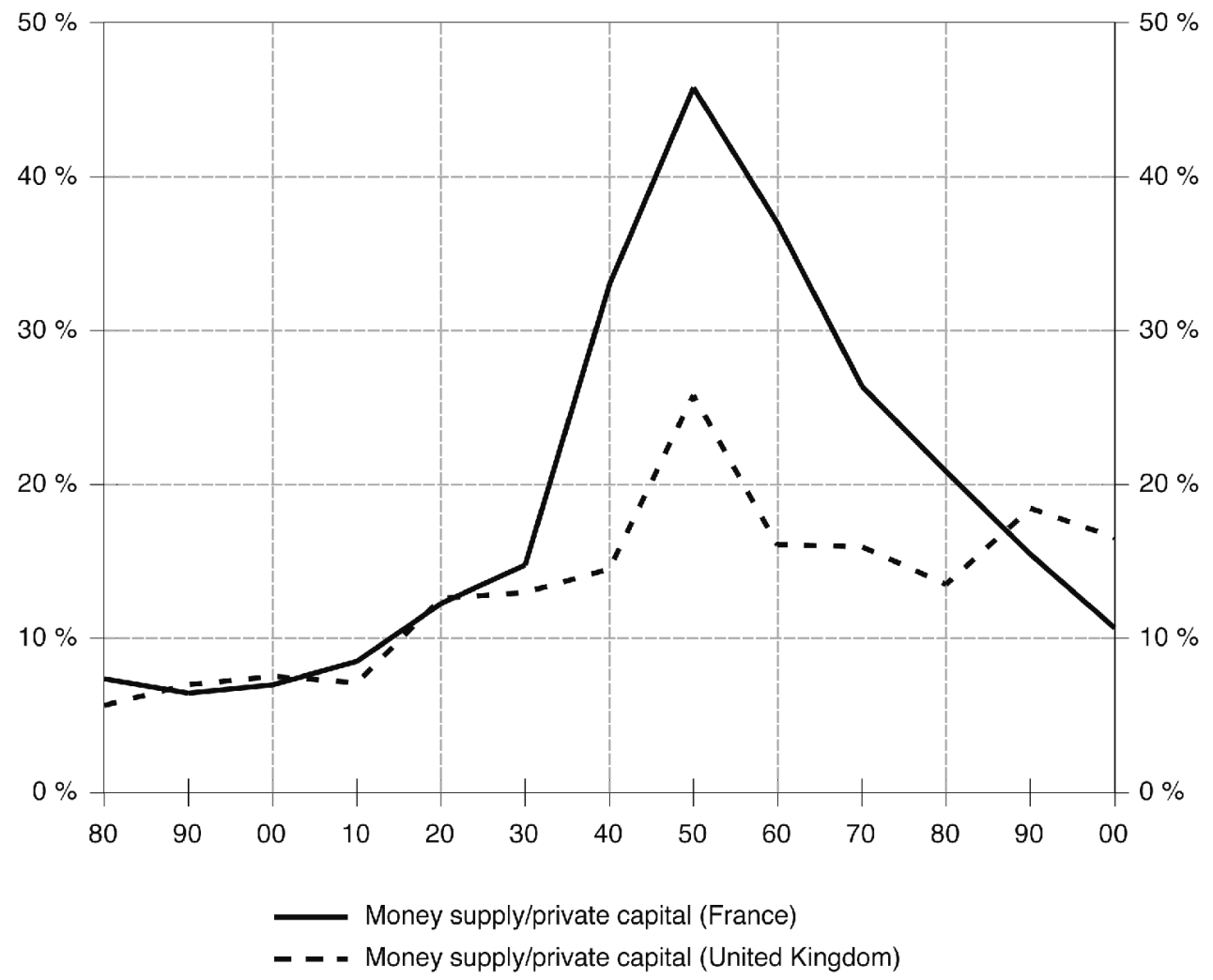

Sources: Schularick and Taylor, "Credit Booms Gone Bust"; Piketty, Capital. Personal wealth and capital are synonymous here, and include the money supply. The datasets thus represent the share of money in overall personal wealth.

reflections on housing rentals and on slavery, more work remains to be done in order to calculate which effective rates of return economic agents might have had access to, and thus whether the variations within the distribution of capital might be explained by price effects (i.e., by changes in the rates of return on capital) or by institutional effects that cannot be reduced to these rates of return.

Focusing on money supply datasets also leads to a different interpretation of the real rate of return on capital during the Golden Age of western European growth (the postwar decades, known in France as the "Thirty Glorious Years"), during which the money supply may have counted for between a third and half of the total stock of capital in France and the real rate of return on capital reached its maximum value. ${ }^{21}$ If the monetary part of capital was really so large, then this rate of return was actually not entirely "real," but rather largely "nominal." 


\section{The Various Types of Capital and the Consequences of Inflation}

A second way to extend the argument would be to look more specifically at the possibilities of substituting the various types of capital and identify their historical manifestations, particularly the influence of inflation or of political decisions upon them. ${ }^{22}$ Substitution can occur not only between cash held and nonfinancial capital, as I discussed above, but also, for instance, between cash held and nonmonetary financial assets within financial capital. We have seen that Piketty makes a distinction between nominal assets and real assets, with the latter not subject to inflation. This means that in times of high inflation it is in the interest of households and banks to reallocate their investments toward real assets. One consequence of this is a diminution of resources available to the state. Insofar as it cuts down the public debt, inflation is advantageous to the Treasury, but the state is nevertheless hurt by the decrease of the real rate of return of its bonds and obligations and their subsequent loss of attractiveness. A possible reaction to this situation might then be to attempt to coerce some economic agents, especially the banks, into holding Treasury bonds; such a policy was applied in France and numerous other countries during the inflationist crises that immediately followed the Second World War. ${ }^{23}$ This is just one example of public policies that aim to orientate savings, and therefore capital, most often toward assets with lower real rates of return-what some economists have called "financial repression." ${ }^{24}$ Piketty mentions these policies only in passing, while discussing the difference between private and public capital. Much work remains to be done to recontextualize these policies of savings orientation within the long-term history of capital accumulation.

Another major issue linked to the substitutability of real and nominal capital arises from the distributive consequences of inflation. On this score the datasets published in Capital in the Twenty-First Century already constitute a sizeable contribution to the debate, since they show conclusively that high inflation during the 1970s in Europe and the United States did not bring about a reduction of inequality in personal wealth, any more than deflation in the 1930 s had led to the reconstitution of the largest fortunes. ${ }^{25}$ Thus, over the century, only the episodes of hyperinflation that occurred during or immediately after the two world wars may have had significant effects on the accumulation of, and inequalities in, personal

22. As I observed earlier, Keynes offers some leads for further investigation, since, according to him, capital accumulation can be explained by the difference between the marginal rate of return on it and the rate of interest on money.

23. Éric Monnet, "Monetary Policy without Interest Rates: Evidence from France's Golden Age (1948-1973)," American Economic Journal: Macroeconomics 6, no. 4 (2014): 137-69; Éric Monnet and Anna Kelber, "Macroprudential Policy and Quantitative Instruments: a European Historical Perspective," Financial Stability Review 18 (2014): 151-60.

24. Ronald McKinnon, Money and Capital in Economic Development (Washington: Brookings Institution, 1973). 
wealth-and even then it is hard to assess their real influence separately from the physical destruction of capital that took place simultaneously. Piketty does not develop such an analysis in his book, but this observation buttresses his assertion that an increase in inflation, up to a yearly rate of 10 percent, for instance, would not be enough to generate any large shift in the unequal distribution of personal wealth. To achieve such a shift would require a period of hyperinflation, with prices doubling from year to year-but the economic and social consequences would be uncontrollable. This is the reason why his book argues for a tax on capital rather than advocating taxation through inflation. One should note however that it would not be possible to target money (or at least, fiat money) with a tax on capital, a fact that would pave the way for a transfer of nonmonetary capital toward monetary capital. In this case, maintaining the effectiveness of a tax on capital would require a high rate of inflation as an auxiliary tool. This might even take place through an automatic process outside of any governmental action, since economic agents faced with a high tax rate on capital would transfer their nonmonetary assets toward monetary assets; the money supply would thus increase while incomes would not, which in turn would push inflation upward. Further study is thus needed on how, in the past, inflation may have played a complementary role in the few attempts at experimentation with capital taxation.

\section{The Politics of Capital Accumulation and Monetary Stability}

Reopening the theoretical discussion of the issues raised by the transformation of money into capital, based on the study of the long-term evolution of both of these variables, provides a third possible path along which to pursue Piketty's analysis. One way to approach these issues from a historian's point of view would be to begin with the theories insisting on the crucial role of trust in monetary exchanges and on the fact that money is a social relationship. ${ }^{26}$ This idea raises an apparently simple question that has nevertheless received no definite answer so far: In what way does monetary stability (and the safeguarding of trust within exchanges) favor the accumulation of real capital, even though the latter is theoretically not influenced by inflation? What kind of links could there be between monetary regimes and the regimes of capital accumulation? Thus, the classical gold standard (1880-1914) was obviously a specific monetary regime, which influenced capital accumulation because of the particular way that money was regulated. Monetary stability was seen as a much broader issue than simply maintaining an exchange rate; it also included pledges over the way the public debt and the free circulation of investments would be managed, which had particularly strong effects on the circulation, and consequently the accumulation, of capital. ${ }^{27}$ A second example can

\footnotetext{
26. See in particular André Orléan, "L'approche institutionnaliste de la monnaie: une introduction," in What about the Nature of Money? A Pluridisciplinary Approach, ed. Virginie Monvoisin, Jean-François Ponsot, and Louis-Philippe Rochon (forthcoming).

27. Michael Bordo and Hugh Rockoff, "The Gold Standard as a 'Good Housekeeping Seal of Approval,”' Journal of Economic History 56, no. 2 (1996): 389-428.
} 
be drawn from the way the fear of monetary depreciation came to be combined with the fear of a tax on capital in France in the 1920s. ${ }^{28} \mathrm{~A}$ last example is provided by the arguments used by central banks throughout the 1970s to legitimize their targeting of the money supply, which invoked the need to mobilize savings by reassuring small investors and providing them with anchored expectations that allowed them to calculate their real rate of return more easily. ${ }^{29}$ In these various examples, the distinction that Marx made between money used in transactions and money used for capital accumulation fades away, and it becomes necessary to move beyond an accounting approach to capital to understand the extent to which money is a specific type of capital, over and above its simple role as a tool in transactions.

Reflecting on the many contributions that Capital in the Twenty-First Century makes to our understanding of the links between money and capital points to some fundamental questions that monetary and financial history will have to answer. Money not only makes up a far from negligible proportion of the capital accounted for by Piketty (almost half in certain countries by the mid-twentieth century) - a fact that should prompt us to study its role and to differentiate it from real assets. It also plays a specific role as the means by which other kinds of capital are accumulated. As in many other domains, Piketty's work both maps out new territory and revives debates that have regrettably been neglected by economic theoreticians. In what way does money contribute to the accumulation of nonmonetary capital? What are the possible substitution effects between capital and money, and what forms did they take historically, with which variations depending on the individuals, the businesses, and the governments concerned? What were the historical consequences of combining inflation and a tax on capital? Was substitutability between various assets governed by arbitraging concerns or by institutional pressures? All these questions remain open, and we would be remiss not to confront them head-on.

\author{
Éric Monnet \\ Banque de France ${ }^{30}$
}

28. Pierre-Cyrille Hautcœur and Pierre Sicsic, "Threat of a Capital Levy, Expected Devaluation and Interest Rates in France during the Interwar Period," European Review of Economic History 3, no. 1 (1999): 25-56.

29. Éric Monnet, "La politique de la Banque de France au sortir des Trente Glorieuses. Un tournant monétariste ?," Revue d'histoire moderne et contemporaine 62, no. 1 (2015): 147-75; Duncan Needham, UK Monetary Policy from Devaluation to Thatcher, 1967-1982 (New York: Palgrave Macmillan, 2014).

30. The content of this article and the opinions expressed therein are the sole responsibility of the author and do not necessarily reflect those of the Banque de France or of the Eurosystem. 